\title{
Characteristics and controlling factors of compound specific sulfur isotope in lacustrine oils and source rocks
}

\author{
Li Sumei ${ }^{1 *}$, Ke Changwei ${ }^{1}$; PAUl GreEnWoOD ${ }^{2}$ \\ ${ }^{1}$ State Key Laboratory of Petroleum Resource and \\ Prospecting, China University of Petroleum (Beijing), \\ Beijing 102249, China (*correspondence: \\ smli@cup.edu.cn) \\ ${ }^{2}$ University of Western Australia, Perth, WA, 6009, Australia \\ (paul.greenwood@uwa.edu.au)
}

The development of compound specific sulfur isotope analysis (CSSIA $)^{[1]}$ enabled detailed studies on the origin, evolution and fate of organic $\mathrm{S}$ as well as its application in petroleum exploration and exploit. The aim of this study was to investigate the composition especially main controlling factors of the compound specific sulfur isotope in saline and freshwater lacustrine oils and source rocks in the Dongpu Depression, Bohai Bay Basin.

The saline lacustrine oils studied are featured by a wide range of the $\delta^{34} \mathrm{~S}$ of organosulfur compounds (OSCs) within and between oils. On the contrary, the freshwater lacustrine oil displays a relatively low and consistent $\delta^{34} \mathrm{~S}$ of OSCs. A negative relationship was observed between $\mathrm{Pr} / \mathrm{Ph}$ ratios and the maximum deviation of the $\delta^{34} \mathrm{~S}$ for the $\mathrm{C}_{1}-\mathrm{C}_{2}$ dibenzothiophenes (DBTs) $\left(\Delta^{34} \mathrm{~S} \max (\mathrm{C} 1 \sim \mathrm{C} 2-\mathrm{DBTs})\right.$ - $\min (\mathrm{C} 1 \sim \mathrm{C} 2$-DBTs $\left.)\right)$ of the crude oils. However, a positive relationship was observed between gammacerane/ $\mathrm{C}_{31}$ hopane, $\mathrm{C}_{29} / \mathrm{C}_{30}$-hopane ratios and $\Delta^{34} \mathrm{~S}_{\max (\mathrm{Cl} \sim \mathrm{C} 2-\mathrm{DBTs})}-\min (\mathrm{C} 1 \sim \mathrm{C} 2-\mathrm{DBTs})$, respectively, suggesting a significantly controlling of redox condition and lithology on $\delta^{34} \mathrm{~S}$ of OSCs. Positive relationship was also observed between $\mathrm{C}_{29} \alpha \alpha \alpha$ sterane20S/(S+R), 4-/1-DBT as well as "resin+asphaltene" content and $\Delta^{34} \mathrm{~S}_{\max (\mathrm{Cl} \sim \mathrm{C} 2-\mathrm{DBTs})}$ $\min (\mathrm{C} 1 \sim \mathrm{C} 2-\mathrm{DBTs})$ of the oils, suggesting obvious maturity impact on $\delta^{34} \mathrm{~S}$. Some of the oils and source rocks was suggested to have been affected by thermochemical sulfate reduction based on report of Cai et al (2015) ${ }^{[2]}$. Oil-source rock correction according to CSSIA show an intermediate fingerprint between the Eogene $\mathrm{Es}_{3}{ }^{\mathrm{L}}-\mathrm{Es}_{4} \mathrm{U}$ and $\mathrm{Es}_{3}{ }^{\mathrm{M}}$ intervals of the oils from the Wenliu Oilfield in the depression, suggesting two main potential source rocks in the area, which provided further evidences of the main source rocks besides of approach of biomarkers.

This work is supported by National Natural Science Foundation of China (41673055 and 41473047).

[1] Amrani et al., 2009. Analytical Chemistry, 81:9027-9034.

[2] Cai et al., 2015. Organic Geochemistry 83-84,140-152. 